\title{
Regulating Innovation for Financial Inclusion: Lessons from Nigeria
}

\author{
Nwanneka Victoria Ezechukwu* 우 \\ Sheffield University, Sheffield, UK \\ E-mail: n.v.ezechukwu@sheffield.ac.uk
}

\begin{abstract}
Innovative services such as mobile payments are potentially transformative because they can increase access to financial services, especially in developing countries. However, such innovations can disrupt the financial services ecosystem, prompting regulators to respond in different ways. These regulatory responses often have a significant impact on the success of such innovative services. Using Nigeria's regulatory approach as a case study, this article highlights specific lessons that should inform future attempts at regulating mobile payments.
\end{abstract}

\section{Keywords}

Mobile payments, financial inclusion, Central Bank of Nigeria, regulation, mobile network operators, m-pesa, payment service banks

\section{INTRODUCTION}

Domont-Naert identifies that basic financial services include access to a bank account, payment services, credit, insurance and protection against overindebtedness. ${ }^{1}$ Where persons cannot access these financial services, they are said to be financially excluded. Financial exclusion is a problem in many developing countries. Banks traditionally provide services through branch networks that are often situated in profitable urban areas. ${ }^{2}$ However, a significant populace resides in rural areas where poverty rates are high. Establishing bank branches and automated teller machines (ATMs) to cover

* Lecturer, Sheffield University.

1 F Domont-Naert "The right to basic financial services: Opening the discussion" (2000) Cambridge Law Journal 63 at 67-69, cited in P Cartwright "The vulnerable consumer of financial services: Law, policy and regulation" at 39, available at: <https:/www.no ttingham.ac.uk/business/businesscentres/gcbfi/documents/researchreports/paper78. pdf> (last accessed 2 July 2021).

2 E Gibson, F Lupo-Pasini and RP Buckley "Regulating digital financial services agents in developing countries to promote financial inclusion” (2015) Singapore Journal of Legal Studies 26 at 26. 
rural areas is expensive. ${ }^{3}$ Hence, many rural dwellers have either no access or limited access to bank services.

The implication is that financially excluded persons cannot save or access credit and, thus, cannot insure themselves against unexpected economic shocks like illness or unemployment. ${ }^{4}$ Hence, such consumers remain vulnerable in circumstances that exacerbate poverty. ${ }^{5}$ Consequently, financial inclusion, which denotes the provision of affordable, basic financial services to excluded and underserved persons, increasingly features as a development priority. ${ }^{6}$ Many financial services regimes now include issues such as "financial inclusion, equity or accessibility of regimes" as core policy considerations, ${ }^{7}$ functioning alongside their core responsibilities of promoting financial stability, integrity and protecting consumers. ${ }^{8}$ This is informed by the belief that, in the absence of intervention, the financial services sector is unlikely to serve persons who are underprivileged due to disability, poverty and geographic disadvantage. ${ }^{9}$

3 C Alexandre, I Mas and D Radcliffe "Regulating new banking models to bring financial services to all” (2011) 54/3 Challenge 116 at 117.

$4 \quad$ RP Buckley, J Greenacre and L Malady “The regulation of mobile money in Malawi” (2015) 4 Washington University Global Studies Law Review 435 at 440.

5 Cartwright "The vulnerable consumer", above at note 1 at 37.

6 E Lee "Financial inclusion: A challenge to the new paradigm of financial technology, regulatory technology and anti-money laundering law" (2017) 6 Journal of Business Law 473 at 473; RP Buckley, DW Arner and M Panton "Financial innovation in east Asia" (2014) 37 Seattle University Law Review 307 at 347. This policy focus is reflected in key documents emanating from international policy standard setting bodies. See, for instance, Global Partnership for Financial Inclusion (GPFI) "Global standard-setting bodies and financial inclusion for the poor: Toward proportionate standards and guidance" (October 2011), available at: <https:/www.gpfi.org/sites/gpfi/files/documents/WhitePaper-Global-Standard-Setting-Bodies-Oct-2011.pdf> (last accessed 2 July 2021); GPFI "Global standard-setting bodies and financial inclusion: The evolving landscape" (2016), available at: <https://www.gpfi.org/publications/global-standard-setting-bodiesand-financial-inclusion-evolving-landscape> (last accessed 2 July 2021); GPFI "G-20 principles for innovative financial inclusion”, available at: <https://www.gpfi.org/sites/gpfi/fil es/documents/G20\%20Principles\%20for\%20Innovative\%20Financial\%20Inclusion $\% 20-\%$ 20AFI\%20brochure.pdf> (last accessed 2 July 2021).

7 R Bollen "A discussion of best practice in the regulation of payment services: Part 2" (2010) 25/9 Journal of International Banking Law \& Regulation 429 at 432.

8 These are collectively described as "I-SIP" objectives: O Tomilova and M Valenzuela "Financial inclusion + stability, integrity, and protection (I-SIP): Policy making for an inclusive financial system" (November 2018) at 1-2, available at: <https://www.cgap. org/sites/default/files/publications/Toolkit-ISIP-Nov-2018_1.pdf> (last accessed 2 July 2021).

9 Bollen "A discussion of best practice", above at note 7 at 432 . Other considerations drive financial inclusion policies. For example, regulatory interest in financial inclusion may be fuelled by concern that a country's financial integrity objectives will be undermined if a large percentage of transactions occur outside the scope of the regulated formal financial sector: L de Koker "Aligning anti-money laundering, combatting of financing of terror and financial inclusion” (2011) 18/4 Journal of Financial Crime 361 at 363. 
Technological innovations that present opportunities for expanding access to financial services have boosted financial inclusion agendas. These innovations cover a range of activities, including offering credit, processing payments, issuing currencies and managing assets, to name a few. ${ }^{10}$ One such innovation is mobile payments (m-payments). ${ }^{11}$ Belonging to a bouquet of mobile-based financial services, m-payments cover payment transactions in which a mobile device is used to initiate, authorize and confirm an exchange of financial value. ${ }^{2}$

M-payments have generated attention in the financial inclusion discourse for several reasons. First, statistics show that the number of mobile phones in circulation exceeds any other technical device that could be used to market, sell or deliver products and services to consumers. ${ }^{13}$ In many developing countries, there has been direct implementation of mobile infrastructure rather than a progression from landline to mobile technology, which has facilitated the growth in mobile phone ownership. ${ }^{14}$ Being ubiquitous, mobile phones present a practical and cost-effective channel for extending financial services to unbanked persons. ${ }^{15}$ Moreover, in these countries, the adoption of mobile-based financial services has been accelerated by the need to address infrastructure gaps that arise when mobile penetration is high, but physical banking infrastructure is deficient. ${ }^{16}$

Secondly, certain success stories lend credence to the potential of m-payments to drive financial inclusion. In particular, Kenya's success with its m-payment product "m-pesa" remains a reference point in this regard.

10 R Van Loo "Making innovation more competitive: The case of fintech" (2018) 65 UCLA Law Review 232 at 238.

11 In some literature, broader terms such as "branchless banking" are used to describe m-payments. See G Ivatury and I Mas "The early experience with branchless banking" (April 2008), available at: <https://www.cgap.org/sites/default/files/researches/do cuments/CGAP-Focus-Note-The-Early-Experience-with-Branchless-Banking-Apr-2008.pdf> (last accessed 2 July 2021).

12 YA Au and RJ Kauffman "The economics of mobile payments: Understanding stakeholder issues for an emerging financial technology application" (2007) 7 Electronic Commerce Research and Applications 141 at 141.

13 T Dahlberg, N Mallat, J Ondrus and A Zmijewska "Past, present and future of mobile payments research: A literature review" (2008) 7 Electronic Commerce Research and Applications 165 at 165.

14 S Rosenberg "Better than cash? Global proliferation of payment cards and consumer protection policy" (2006) 60 Consumer Financial Law Quarterly Report 426 at 437, cited in A Angelovska-Wilson and J Fetault "M-payments - the next payments frontier: Current developments and challenges in the international implementation of m-payments" (2007) Journal of International Banking Law E Regulation 575 at 585.

15 JK Winn and L de Koker "Introduction to mobile money in developing countries: Financial inclusion and financial integrity" (2013) 8/3 Washington Journal of Law Technology \& Arts 155 at 162.

16 F Arner, W Douglas, J Barberis and RP Buckey "FinTech, regtech, and the reconceptualization of financial regulation" (2017) 37 Northwestern Journal of International Law $\mathcal{E}$ Business 371 at 380 . 
Introduced in 2007, m-pesa is a low-cost SMS-based person-to-person money transfer platform that supports the deposit, transfer and withdrawal of funds using mobile phones. ${ }^{17}$ Since its introduction, m-pesa has assisted in improving access to payment services in Kenya. Total account ownership ${ }^{18}$ in Kenya grew from 42 per cent in 2011 to 81 per cent in $2018 .{ }^{19}$ More adults have mobile money accounts (72.9 per cent) in comparison to accounts with traditional institutions (55.7 per cent). ${ }^{20}$

M-pesa's success has inspired regulators to prioritise financial inclusion. In 2009, two years after m-pesa's launch, the Central Bank of Nigeria (CBN) designed a regulatory framework for m-payment services in Nigeria. ${ }^{21}$ Despite this effort, Nigeria has failed to replicate m-pesa's success. Reflecting on Nigeria's approach to regulating m-payments, this article aims to highlight specific regulatory lessons that can inform future attempts at regulating m-payments. To this end, the article is structured as follows. After this introduction, the next part of the article reviews key aspects of the regulatory framework for m-payments in Nigeria. Building on this, the article then highlights specific lessons that can be extracted from Nigeria's regulatory experience. The next section puts forward alternative considerations that should inform the regulation of m-payments before concluding the discussion.

\section{THE REGULATORY FRAMEWORK FOR MOBILE PAYMENTS IN NIGERIA}

In 2010, 46.3 per cent of Nigerian adults were financially excluded. ${ }^{22}$ With such numbers, it was unsurprising that, in 2011, the CBN committed to reducing exclusion under the Maya Declaration spearheaded by the Alliance for Financial Inclusion at its Global Policy Forum in Mexico. ${ }^{23}$ The Maya Declaration represents "the first global commitment by policymakers from developing and emerging countries to unlock the economic and social

17 MW Buku and MW Meredith "Safaricom and m-pesa in Kenya: Financial inclusion and financial integrity” (2013) 8 Washington Journal of Law, Technology E Arts 375 at 378.

18 The World Bank defines account ownership to include accounts held at a financial institution and those held with a mobile money provider: "Account ownership" (2017), available at: <https://globalfindex.worldbank.org/sites/globalfindex/files/chapters/2017\% 20Findex\%20full\%20report_chapter1.pdf> (last accessed 2 July 2021).

19 The Little Data Book on Financial Inclusion (World Bank, 2018) at 84, available at: <https:// openknowledge.worldbank.org/bitstream/handle/10986/29654/LDB-FinInclusion2018. pdf? sequence= 1 \&isAllowed=y (last accessed 2 July 2021).

20 Ibid.

21 CBN "Regulatory framework for mobile payment services in Nigeria" (2009), available at: <https://www.cbn.gov.ng/OUT/CIRCULARS/BOD/2009/REGULATORY\%20FRAMEWORK \%20\%20FOR\%20MOBILE\%20PAYMENTS\%20SERVICES\%20IN\%20NIGERIA.PDF> (last accessed 2 July 2021).

22 CBN "National financial inclusion strategy" (2012), available at: <https://www.cbn.gov. ng/Out/2013/CCD/NFIS.pdf> (last accessed 2 July 2021).

23 Available at: <https://www.afi-global.org/maya-declaration> (last accessed 2 July 2021). 
potential of the poor through greater financial inclusion". ${ }^{24}$ In line with its commitments under the declaration, the CBN launched a National Financial Inclusion Strategy (NFIS) in 2012. ${ }^{25}$ A principal goal identified in the NFIS was to increase access to payment services from 21.6 per cent in 2010 to 70 per cent in $2020 .^{26}$ The CBN identified m-payments as one of the key drivers in meeting this target. ${ }^{27} \mathrm{M}$-payments were singled out because of the high mobile penetration rates at the time. ${ }^{28}$ This article divides the key aspects of the CBN's regulatory response into two phases, discussed below.

\section{Phase I: 2009-14}

This phase reflects initial attempts to regulate m-payments primarily through the introduction of a licensing regime. Before releasing the NFIS, the CBN issued key regulatory documents applying to m-payments. First, in 2009, it released a document entitled "The Regulatory Framework for Mobile Payments in Nigeria" (the Framework). ${ }^{29}$ In 2014, it released a second document entitled "Guidelines on Mobile Money Services in Nigeria" (the Guidelines), which updated the Framework. ${ }^{30}$

The Guidelines outline the three objectives informing the CBN's intervention. First, the intervention aimed to "ensure a structured and orderly development of mobile payment services in Nigeria, with clear definition of various participants and their expected roles and responsibilities". ${ }^{31}$ Secondly, it aimed to specify the minimum technical and business requirements for the various participants in the recognized m-payments industry. ${ }^{32}$ Thirdly, it sought to promote the safety and effectiveness of m-payment services to enhance user confidence. ${ }^{33}$

Under the Guidelines, only licensed entities designated as "mobile money operators" (MMOs) may provide m-payment services. ${ }^{34}$ The Guidelines permit two business models that MMOs can adopt in providing the services: the bank-led model and the non-bank led model. ${ }^{35}$ The bank-led model is one in which the service provider is a bank, acting either alone or in a consortium with other banks. In this model, banks may choose to partner with other approved organizations but remain principally responsible for delivering

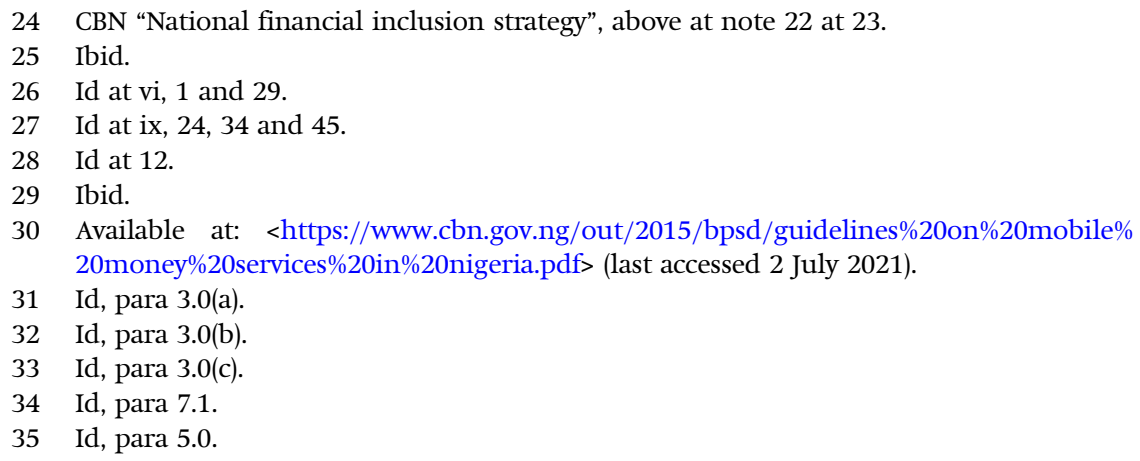


the services. ${ }^{36}$ In the non-bank model, a corporate organization, other than a bank, may be licensed to deliver m-payments. While not defining which organizations qualify to lead a non-bank model, the Guidelines expressly exclude mobile network operators (MNOs) from the model's scope. ${ }^{37}$ The CBN justified this exclusion on the basis that MNOs would pose a threat to the stability of the financial system. This is because MNOs lack the experience of implementing financial regulations and would expose the financial system to systemic risks. ${ }^{38}$

The Guidelines limited MNOs' role to providing the telecommunication network infrastructure for use by MMOs. ${ }^{39}$ To this end, MNOs are required to implement a secure communications channel that is compliant with the technology standard stipulated in the Guidelines. ${ }^{40}$ To encourage competition, MNOs are precluded from giving preferential treatment to any specific MMO in terms of price and traffic. ${ }^{41}$ Furthermore, MNOs must ensure that their subscribers are free to use any m-payment service of their choice. ${ }^{42}$ Reiterating their exclusion from providing payment services, the Guidelines enjoin MNOs not to receive deposits from the public except for their subscribers' airtime billing. ${ }^{43}$ They are also precluded from allowing the use of prepaid airtime value loaded by their subscribers to transfer monetary value or for payment purposes. ${ }^{44}$

Although the CBN released the Framework in 2009, it only began to receive applications for licences in 2010. By 2014, the CBN had issued licences to 21 MMOs. ${ }^{45}$ During this period, some banks had begun to include m-payment services as part of the suite of services available on their mobile banking platforms. Many non-banks that received a licence were unable to commence operations due to limited funds to build the required infrastructure and agent networks. ${ }^{46}$ The few non-bank platforms that were operational ${ }^{47}$ did not gain

36 Id, para 5.0(a).

37 Id, para $5.0(\mathrm{~b})$.

38 GSMA "What could we learn from Nigeria barring MNOs from participating in the mobile money market?” (29 April 2013), available at: <https://www.gsma.com/mobil efordevelopment/region/sub-saharan-africa-region/what-could-we-learn-from-nigeriabarring-mnos-from-participating-in-the-mobile-money-market/> (last accessed 2 July 2021).

39 The Guidelines, para 8.4. See also CBN "Regulatory framework", above at note 21, para 2.1 .

40 The Guidelines, para 8.4(b).

41 Id, para $8.4(\mathrm{c})$ and (h).

42 Id, para $8.4(\mathrm{~d})$.

43 Id, para $8.4(\mathrm{e})$.

44 Id, para $8.4(\mathrm{f})$.

45 See CBN "Financial service providers", available at: <https://www.cbn.gov.ng/FinInc/fins ervproviders.asp> (last accessed 2 July 2021).

46 J Agumagu "Mobile money: Boosting financial inclusion via recapitalization" (8 February 2018) New Telegraph, cited in USAID "The digital financial services landscape in Nigeria: Enabling market conditions for pay-as-you-go-solar" (2018), para 3.1.3.7, available at: <https://www.usaid.gov/sites/default/files/documents/1860/Enabling_Market_Conditions_ for_Pay-As-You-Go_Solar_Executive_Summary.pdf> (last accessed 15 July 2021).

For example, Pagatech and Etranzact. 
the traction comparable to counterparts like m-pesa. This was probably because they were not recognizable brands that could inspire consumer trust and they did not have extensive agent networks.

\section{Phase II: 2015-2020}

Despite the number of licences issued in the first phase, the m-payment market failed to record significant success in Nigeria. A 2016 survey revealed that 76 per cent of Nigerians were unfamiliar with mobile money and 98.7 per cent had never registered for or used a mobile money service. ${ }^{48}$ Owing to this failure, the CBN began to embrace regulatory shifts, most of which focused on ensuring that MMOs could access agent networks of other stakeholders, like MNOs. The CBN's focus is explained by its admission that, "agent networks present an opportunity to service people in areas that lack bank branches or other physical financial access points like ATMs. Consequently, a functional agent network is imperative for extending financial services to the unbanked. However, deficit of fixed location agents has been a challenge". 49

In comparison to banks and other firms permitted to provide m-payments, MNOs have a well-dispersed network of existing outlets across Nigeria. In 2015, a geospatial mapping survey of MNO access points captured about 8,533 operational outlets in Nigeria's 36 states and Federal Capital Territory. ${ }^{50}$ Thus, the $\mathrm{CBN}$ recognized that the MNOs' networks and recognizable brands could be leveraged in driving the market.

Accordingly, in 2015, the CBN released the Regulatory Framework for Licensing Super Agents in Nigeria. ${ }^{51}$ Super-agents are parties contracted to act on behalf of financial institutions. This framework aims to encourage stakeholders like MNOs to share their agent networks with financial services providers like MMOs. ${ }^{52}$ MNOs licensed under this framework are granted "super-agent" status and are permitted to sub-contract other agents for

48 Enhancing Financial Innovation and Access "EFInA access to financial services in Nigeria (A2F) 2016 survey" at 32 and 35, available at: <https://www.efina.org.ng/wp-content/uplo ads/2019/03/Key-Findings-A2F-2016.pdf> (last accessed 2 July 2021).

49 CBN "Exposure draft of the national financial inclusion strategy refresh" (6 July 2018) at 27, available at: <https://www.cbn.gov.ng/Out/2018/CCD/Exposure\%20Draft\%20of\% 20the\%20National\%20Financial\%20Inclusion\%20Strategy\%20Refresh_July\%206\%202018. pdf> (last accessed 2 July 2021).

50 CBN 2016 Annual Report: National Financial Inclusion Strategy Implementation at 64, available at: <https://www.cbn.gov.ng/out/2017/ccd/2016\%20annual\%20report\%20on\% 20nfis\%20implementation.pdf> (last accessed 15 July 2021).

51 Available at: <https://www.cbn.gov.ng/out/2015/bpsd/regulatory\%20framework\%20for \%20licensing\%20super-agents\%20in\%20nigeria.pdf> (last accessed 2 July 2021) (Super Agents Licensing Framework).

52 Alliance for Financial Inclusion "Central Bank of Nigeria approves first super agent banking licenses” (1 August 2016), available at: < https://www.afi-global.org/news/ 2016/08/central-bank-nigeria-approves-first-licenses-super-agent-banking> (last accessed 2 July 2021). 
whom they will be responsible. ${ }^{53}$ The scope of banking-related activities that super-agents or agents can undertake is defined under the CBN's Guidelines for the Regulation of Agent Banking and Agent Banking Relationships in Nigeria. ${ }^{54}$ Functions with which agents can assist include accepting cash deposits and withdrawals, bills and salaries, and local funds transfer. ${ }^{55}$ Super-agents can only use their platform to manage their agents' activities and are precluded from holding electronic money. ${ }^{56}$ Only licensed financial institutions remain permitted to provide and operate mobile money platforms and to hold electronic money. ${ }^{57}$

The CBN, in collaboration with relevant stakeholders, also launched the Shared Agent Network Expansion Facility programme to encourage the development and sharing of agent networks. ${ }^{58}$ Under this programme, participating institutions can share agents in rolling out financial services. This programme and the Super Agents licensing regime viewed MNOs as "distribution actors", 59 whose agent networks could be exploited. They remained excluded from taking the lead in providing services like m-payments.

In 2018, the CBN revised the NFIS. ${ }^{60} \mathrm{~A}$ key issue recognized in the implementation of the 2012 NFIS was that mobile money had failed to take off, owing to restrictive policies. ${ }^{61}$ The revised NFIS highlighted overarching policy principles that would inform its implementation. The first principle hinges on the adoption of an appropriate risk-based regulatory level playing field that ensures that the same set of regulatory requirements and conditions applies to all potential providers of a particular service, regardless of their background or type of operation. ${ }^{62}$ The second principle focuses on encouraging relevant actors to play to their core areas of strength to achieve high impact.

These principles appear to have set the tone for the policy change heralded by the introduction of the Guidelines for the Licensing and Regulation of Payment Service Banks in Nigeria (PSB Guidelines). ${ }^{63}$ The PSB Guidelines

53 Super Agents Licensing Framework, above at note 51, para 4.0.

54 Available at: <https://www.cbn.gov.ng/out/2013/ccd/guidelines\%20for\%20the\%20regul ation $\% 20$ of $\% 20$ agent $\% 20$ banking\%20and\%20agent $\% 20$ banking $\% 20$ relationships $\% 20$ in $\%$ 20nigeria.pdf> (last accessed 2 July 2021).

55 Id, para 6.2.

56 Super Agents Licensing Framework, above at note 51, para 6(a)(ii).

57 Ibid.

58 See: <https://www.sanefng.com/about-sanef> (last accessed 2 July 2021).

59 CBN "Exposure draft", above at note 49 at 5.

60 Available at: <https://www.cbn.gov.ng/out/2019/ccd/national\%20financial\%20inclusion \%20strategy.pdf> (last accessed 2 July 2021).

61 Id at vi.

62 Id at vii.

63 Available at: <https://www.cbn.gov.ng/Out/2018/FPRD/OCTOBER\%202018\%20EXPOSURE\% 20PAYMENT\%20BANK.pdf> (last accessed 2 July 2021). These were revised in August 2020; see CBN "Guidelines for licensing and regulation of payment service banks in Nigeria" (August 2020), available at: <https://www.cbn.gov.ng/Out/2020/CCD/APPROVED\%20 REVIEWED\%20GUIDELINES\%20FOR\%20LICENSING\%20AND\%20REGULATION\%20OF\% 
provide the framework for licensing niche banking institutions, called payment service banks (PSBs). The main objective behind setting up PSBs is to "enhance financial inclusion in rural areas by increasing access to deposit products and payment / remittance services ... through high-volume low value transactions in a secured technology-driven environment". ${ }^{64}$ PSBs are permitted to maintain savings accounts and to accept deposits. They can also provide payment and remittance services and may operate an electronic purse. ${ }^{65}$ They cannot, however, grant loans, advances or guarantees. ${ }^{66}$

In what appears to be a significant departure from the previous policy stance, the PSB Guidelines permit MNOs, through subsidiaries, to register as PSBs. Under this framework, MNOs may provide payment services if they meet the licensing requirements and are granted approval-in-principle. ${ }^{67}$ In September 2019, the CBN issued approvals-in-principle to three entities, two of which are controlled by MNOs. ${ }^{68}$ While it is still too early to assess whether the inclusion of MNOs as eligible promoters of PSBs will drive the m-payment market, Nigeria's experience so far and this policy U-turn provide some lessons that can inform future attempts at regulating m-payments.

\section{MATTERS ARISING: WHAT LESSONS CAN WE LEARN?}

\section{The participation of mobile network operators may be decisive in the successful roll-out of mobile payments}

The CBN's evolving position on MNOs directly providing m-payments raises questions about the MNOs' role in driving the market. This article takes the position that the CBN's initial exclusion of MNOs from direct participation was detrimental to the growth of the m-payments market. There are several reasons for this view. First, it is supported by inferences from empirical research carried out by Evans and Pircho. ${ }^{69}$ Their study focused on discovering why m-payments succeeded in some countries and failed in others. The study identified eight countries in which m-payments recorded explosive

contd

20 PAYMENT\%20SERVICE\%20BANKS\%20IN\%20NIGERIA-27AUG2020.pdf> (last accessed 2 July 2021).

64 Id, para 2.

65 Id, para 4.1.

66 Id, para 4.2

67 Id, para 6.1.

68 F Eleanya “CBN issues 'approval-in-principle' to Glo, 9Mobile, UP subsidiaries for PSB services” (19 September 2019) Business Day, available at: <https://businessday.ng/technolo gy/article/cbn-issues-approval-in-principle-to-glo-9mobile-up-subsidiaries-for-psb-services/> (last accessed 3 July 2021).

69 DS Evans and A Pircho "An empirical examination of why mobile money schemes ignite in some developing countries but flounder in most" (2015), available at: <https://chicago unbound.uchicago.edu/cgi/viewcontent.cgi?article=2413\&context=law_and_economics> (last accessed 3 July 2021). 
growth. ${ }^{70}$ One common characteristic in these countries, save for one, ${ }^{71}$ was that there was no regulatory restriction on which parties could provide m-payments. In identifying the factors that could stimulate success, the study asserts that "the regulatory framework adopted by the government, in particular, the extent to which regulations restrict potential players, in particular mobile network operators (MNOs), from operating mobile money schemes ... could facilitate or restrain success". ${ }^{72}$

Among 22 countries investigated by Evans and Pircho, there was only one success story that was not driven by an MNO-led scheme. This service, bKash, is sponsored by the BRAC Bank in Bangladesh. The service is reportedly successful because it is supported by the MNOs that account for most subscribers in the country. ${ }^{73}$ However, the service has been mostly useful in providing a platform that allows people to pay bills. Unlike with services that are MNO-led, it has not been successful as a platform for person-to-person transfers. ${ }^{74}$ Pakistan also has a successful bank-led platform, but its experience has been unique. In Pakistan, MNOs are not allowed to provide m-payments direct. To circumvent this, Telenor Pakistan, Pakistan's largest telecoms operator, acquired a 51 per cent stake in Tameer Bank to launch its m-payment service, Easypaisa. ${ }^{75}$ Easypaisa enjoys an extensive agent network backed by Telenor Pakistan's distribution networks. ${ }^{76}$

Evans and Pircho's study appears to confirm that the key to unlocking m-payments rests with flexible regulations that permit direct participation by stakeholders such as MNOs. Their conclusions are supported by a 2017 study carried out by Riley and Kulathunga, investigating four jurisdictions that successfully leveraged electronic money and digital financial services in driving financial inclusion. ${ }^{77}$ They found that the involvement of the private sector and non-bank entities, which were supported by flexibly designed policies, positively impacted financial inclusion statistics. ${ }^{78}$ MNOs are singled out as important stakeholders for several reasons. First, they have a communications network that allows for transactions to be performed in real-time. ${ }^{79}$ Secondly, they operate the subscriber identity module (SIM) cards that provide

70 Bangladesh, Côte d'Ivoire, Kenya, Rwanda, Somaliland, Tanzania, Uganda and Zimbabwe: id at 6 .

71 Bangladesh's case is considered later in this section.

72 Evans and Pircho "An empirical examination", above at note 69 at 10.

73 Id at 17.

74 Ibid.

75 SE Senthe "Transformative technology in microfinance: Delivering hope electronically" (2012) 13 Pittsburgh Journal of Technology Law \& Policy 1 at 19.

76 Evans and Pircho "An empirical examination", above at note 69 at 19.

77 TA Riley and A Kulathunga Bringing E-Money to the Poor: Successes and Failures (World Bank, 2017), available at: <http://documents.worldbank.org/curated/en/3407015035683 46911/pdf/119070-PUB-PUBLIC-PUB-DATE-8-22-17.pdf> (last accessed 3 July 2021).

78 Ibid.

79 C Alexandre, I Mas and D Radcliffe "Regulating new banking models to bring financial services to all" (2011) 54/3 Challenge 116 at 119-20. 
the technology to support SMS-based payment services such as m-pesa. Thirdly, they have easily recognizable brands and a vast retail distribution network of airtime sellers, even in rural areas. ${ }^{80}$ They are also well-experienced in running high-volume, real-time prepaid platforms to a high standard of availability and reliability. ${ }^{81}$

The regulatory shifts occurring in several countries, including Nigeria, also support the conclusion that MNOs' participation is critical in driving the m-payments market. Evans and Pircho's study identified eight countries in which m-payments have failed to ignite. ${ }^{82}$ The study found that all eight (including Nigeria) adopted a heavy-handed approach to regulating m-payments. Of the eight, seven required that banks take the lead or significantly participate in providing the service. ${ }^{83}$ Since the study was published, regulatory shifts have occurred in at least three countries: Ghana, India and Nigeria. ${ }^{84}$ In Nigeria and India, as noted below, central bank authorities have moved from policies prohibiting the direct involvement of MNOs, to policies allowing MNOs to participate in the provision of m-payments through niche financial institutions (payments banks).

In Ghana, the 2008 Guidelines for Branchless Banking favoured a bank-led business model for the provision of m-payments and required that at least three banks be involved in any service. ${ }^{85}$ This approach was described as "many to many" and aimed to encourage interoperability, which would allow the m-payments market to take off swiftly. ${ }^{86}$ MNOs were excluded from applying for licences independently and were required to partner with banks. The m-payments market did not take off as expected. Research by the Consultative Group to Assist the Poor (CGAP) found that banks had little incentive to make significant investments under these arrangements. ${ }^{87}$ MNOs made most of the investments and felt disadvantaged because the regulations did not permit them to take an independent lead in providing the service. ${ }^{88}$ The failure to record success prompted regulatory reform, which saw the passing of new guidelines for e-money issuers in 2015. The 2015 guidelines

\footnotetext{
80 Ibid.

81 Ibid.

82 In respect of Burkina Faso, Haiti, India, Indonesia, Madagascar, Mexico, Nigeria and South Africa, see: Evans and Pircho "An empirical examination", above at note 69 at 6 .

83 Ibid.

84 Sri Lanka also moved from a bank-centric model, thus permitting non-banks to provide m-payments subject to capital requirements: id at 28.

85 Available at: <https://dfsobservatory.com/sites/default/files/Bank\%20of\%20Ghana\% 20-\%20Notice\%20No.\%20BG-GOV-SEC-2008-21\%20-\%20Regulatory\%20Framework\%20for \%20Branchless\%20Banking.pdf> (last accessed 2 July 2021).

86 C Mckay and P Zetterli "Unintentional consequences: Branchless banking in Ghana" (CGAP blog, 3 January 2013), available at: <http://www.cgap.org/blog/unintentional-co nsequences-branchless-banking-ghana> (last accessed 2 July 2021).

87 Ibid.

88 Ibid.
} 
permit MNOs to apply to Ghana's Central Bank for licences. ${ }^{89}$ These regulatory shifts lend credence to the proposition that MNOs are critical in driving the m-payments market.

\section{Clues from Kenya: Flexible regulatory approaches may be more appropriate for innovative financial services like mobile payments}

Nigeria's experience also raises questions about the impact of a chosen regulatory approach in the growth of innovative financial services like m-payments. This issue is significant, because a regulator's approach may provide either the right conditions that encourage innovation or may hinder its growth by compounding the risk already inherent in the acceptance of a novel product. ${ }^{90}$ Further light can be shed on this issue by juxtaposing the approaches of the CBN and Central Bank of Kenya (CBK) in Nigeria and Kenya, respectively. Safaricom, an MNO, provides Kenya's leading m-payment product, m-pesa. When m-pesa was launched in 2007, there were no regulations dedicated to m-payments. As financial inclusion was a policy priority for the CBK, it was interested in the success of m-pesa. ${ }^{91}$ The regulatory approach involved continuous dialogue between the CBK and Safaricom before the product's launch. When Safaricom submitted its proposal, the CBK conducted an internal review, which focused on clarifying specific areas of concern. ${ }^{92}$ First, the CBK was concerned about the legal status of m-pesa: it needed to decide whether to classify it as a banking business. Secondly, it was concerned about the money laundering risks introduced by the product. Thirdly, the CBK sought to understand the operational risks associated with the service.

Following legal advice, the CBK reached several conclusions that informed its regulatory stance. ${ }^{93}$ First, it decided that m-pesa was not a banking service as defined under Kenya's Banking Act. ${ }^{94}$ This was because the cash exchanged for electronic value was not repaid on demand and remained in the

89 Bank of Ghana "Guidelines for e-money issuers in Ghana", para 7, available at: <https:// dfsobservatory.com/sites/default/files/Bank\%20of\%20Ghana\%20-\%20Guidelines\%20for \%20E-Money\%20Issuers\%20in\%20Ghana.pdf> (last accessed 2 July 2021).

90 E Gutierrez and S Singh "What regulatory frameworks are more conducive to mobile banking? Empirical evidence from Findex data" (World Bank policy research working paper no 6652, October 2013) at 3, available at: <http://documents.worldbank. org/curated/en/208411468151504563/pdf/WPS6652.pdf> (last accessed 3 July 2021).

91 AA Lashitew, R Van Tulder and Y Liasse "Mobile phones for financial inclusion: What explains the diffusion of mobile money innovations?” (2019) 48/5 Research Policy 1201 at 1210 .

92 Alliance for Financial Inclusion (AFI) "Enabling mobile money transfer: The Central Bank of Kenya's treatment of m-pesa” (2010) at 4, available at: <http://www.gsma.com/mobil efordevelopment/wp-content/uploads/2013/09/enablingmobilemoneytransfer92.pdf> (last accessed 2 July 2021).

93 Ibid.

94 The Banking Act, 1999 (as amended). 
customer's control. ${ }^{95}$ Secondly, it concluded that there was no credit risk for customers or Safaricom, because m-pesa agents were required to make upfront deposits of cash in m-pesa accounts held by local banks. ${ }^{96}$ Thirdly, the CBK established that there was no intermediation: ${ }^{97}$ customer funds were not lent in the pursuit of other business, interest or income, and all funds were held in a trust account and could not be accessed by Safaricom to fund other parts of its business. ${ }^{98}$ Fourthly, the CBK found that m-pesa was developed with anti-money laundering (AML) measures in mind. There were functions supporting the generation of electronic trails and suspicious transaction monitoring. Transaction caps were also set on individual and aggregate daily transactions and international remittances. ${ }^{99}$ Finally, the CBK concluded that m-pesa's operational risk was minimized as there was end-to-end encryption of the SIM card to ensure security and live back-up. The CBK requested that Safaricom undertake comprehensive technical assessments carried out by Consult Hyperion ${ }^{100}$ to evaluate the operational risks of the m-pesa platform. ${ }^{101}$ The service passed Consult Hyperion's tests for operational capacity. ${ }^{102}$ It was found that there were reporting and monitoring mechanisms that ensured that the CBK could request information concerning the firm's audit trail, AML procedures, liquidity management and clearing / settlement. ${ }^{103}$

The CBK also held consultations with the Communications Authority of Kenya, Safaricom's primary regulator. ${ }^{104}$ These consultations revealed that the authority considered m-pesa to be a value-added service that Safaricom was licensed to offer. ${ }^{105}$ Based on these findings, m-pesa was not regulated as a financial service. The CBK concluded that m-pesa had adequate controls in areas that could affect financial stability and issued it with a letter of no objection. ${ }^{106}$

95 AFI "Enabling mobile money", above at note 92 at 4.

96 Ibid.

97 This is the process by which banks take in funds from a depositor at low-interest rates and lend them out at higher interest rates to make a profit. See Corporate Finance Institute "How do banks make money?", available at: <https://corporatefinanceins titute.com/resources/knowledge/finance/how-do-banks-make-money/> (last accessed 15 July 2021).

98 AFI "Enabling mobile money", above at note 92 at 4.

99 Ibid.

100 This is a specialist consultancy specializing in secure electronic transactions. See Consult Hyperion's website, at: <http://www.chyp.com/> (last accessed 2 July 2021).

101 Riley and Kulathunga Bringing E-Money to the Poor, above at note 77 at 66.

102 Ibid.

103 Ibid.

104 At Safaricom's launch, the regulator was known as the Communications Commission of Kenya.

105 AFI "Enabling mobile money", above at note 92 at 6.

106 CBK released a public statement in 2009 outlining its position on m-pesa: id at 7. 
M-pesa's success has partly been attributed to the liberal regulatory approach of the $\mathrm{CBK},{ }^{107}$ which has been described as a "test and learn" method that is implemented on a case-by-case basis. ${ }^{108}$ With this approach, non-bank providers can benefit from regulatory forbearance, like the "letter of no objection" granted by the CBK or restricted licences or special charters. ${ }^{109}$ In such circumstances:

"In return for the regulator's 'clarification' that the FinTech firm's activity is outside the scope of certain rules which are viewed as unnecessary or inappropriate under the circumstances or in the specific context, the no-action letter or restricted license may be supplemented with conditions seeking to ensure that even if certain rules do not apply, the principles underlying the regulation are still upheld. The practical effect of forbearance through no-action letters, restricted licensing, or special charters is that of partial exemptions or dispensation within a broader regulatory framework."110

The advantage of this approach is that it encourages communication between regulators and innovators. Regulators can study business models and risk assessments and request clarification where needed. ${ }^{111}$ This allows regulators to obtain sufficient data and experience to inform their regulatory response. ${ }^{112}$ However, the main drawback with this approach is that it is more suitable where the number of firms requesting exemptions is small. Where more firms request bespoke exemptions, this will increase costs and put a strain on regulatory capacity. ${ }^{113}$ It may also be challenging to ensure that equal treatment is extended to each participant. ${ }^{114}$ This can lead to unintended consequences. For instance, from a competition perspective, Kenya's approach provided Safaricom with a dominant market position. Safaricom's dominance attracted criticism that forced regulators to call for the implementation of interoperability between m-pesa and other mobile money services. ${ }^{115}$ Such dominance can negatively impact competition, leaving consumers with limited choices, since providers have little incentive to improve the quality of

107 DER Goncalves "Financial inclusion in Peru: Lessons from Kenya's regulatory approach on e-money" (2013) 21 University of Miami International \& Comparative Law Review 31 at 33.

108 DA Zetzsche, RP Buckley, JN Barberis and DW Arner "Regulating a revolution: From regulatory sandboxes to smart regulation" (2018) 23 Fordham Journal of Corporate \& Financial Law 31 at 58 .

109 Ibid.

110 Id at 59.

111 Id at 62.

112 Id at 61-62; DW Arner et al "Fintech and regtech: Enabling innovation while preserving financial stability" (2017) 18 Georgetown Journal of International Affairs 47 at 52.

113 Zetzsche et al "Regulating a revolution", above at note 108 at 62.

114 Ibid.

115 Ibid. 
their services or preserve their reputation. ${ }^{116}$ It can also lead to the creation of "too big to fail" providers, inviting serious consequences. The failure of a large provider like Safaricom can lead to system-wide disruption in the economy and can have serious reputational consequences for regulators. ${ }^{117}$ Such disruptions can also discourage potential users of similar services, which can jeopardize financial inclusion gains.

Zetzsche et al also point out that this approach may lead to long-term uncertainty for businesses. ${ }^{118}$ This suggests that a flexible case-by-case assessment is more appropriate in the early stages of regulating a new product. This approach in the early stages of regulation allows regulators to gather the information and experience required to issue rules that will apply to future innovators. Again, Kenya's experience fits with this. Despite its success, m-pesa highlighted a gap in the regulation of payment services in Kenya. ${ }^{119}$ Consequently, the National Payment Systems Regulations (NPSR) was passed in 2014. The NPSR introduced new regulatory rules for the payment sector and identified the CBK as the primary supervisory authority for payment service providers (PSPs). ${ }^{120}$ The NPSR set out basic e-money rules and require interested firms to apply for authorization or registration. ${ }^{121}$ MNOs may be designated as PSPs or e-money issuers. ${ }^{122}$

Unlike Kenya, Nigeria adopted a less flexible approach to regulating m-payments. The CBN released the Framework document in 2009 before any m-payment service was launched and only began to receive licence applications in 2010. Out of about 40 applicants, only 18 received approvals-in-principle, with a requirement to build m-payment platforms and run pilots within three months. ${ }^{123}$ Certain problems are associated with the CBN's approach.

$116 \mathrm{AB}$ Kernan "Sustaining the growth of mobile money services in developing nations: Lessons from overregulation in the United States" (2018) 51 Vanderbilt Journal of Transnational Law 1109 at 1148.

117 B Fung, M Molico and G Stuber "Electronic money and payments: Recent developments and issues" (discussion paper, 2014-2) at 2, available at: <https://www.bankofcanada. ca/wp-content/uploads/2014/04/dp2014-2.pdf> (last accessed 2 July 2021).

118 Zetzsche et al "Regulating a revolution", above at note 108 at 63-64.

119 AFI "Enabling mobile money", above at note 92 at 6.

120 NPSR, reg 30. Kenya's National Payment System Act (2011), sec 2 defines a "payment service provider" as: “(i) a person, company or organisation acting as provider in relation to sending, receiving, storing or processing of payments or the provision of other services in relation to payment services through any electronic system; (ii) a person, company or organisation which owns, possesses, operates, manages or controls a public switched network for the provision of payment services; or (iii) any other person, company or organisation that processes or stores data on behalf of such payment service providers or users of such payment services."

121 NPSR, reg 4.

122 This is a payment service provider authorized to issue electronic money under the NPSR, reg 2.

123 P Shrivastava "The hold-up with mobile money in Nigeria" (13 August 2015), available at: <https://www.centerforfinancialinclusion.org/the-hold-up-with-mobile-money-in-nigeria> (last accessed 15 July 2021). 
First, the 2009 Framework contained prescriptive requirements dictating the acceptable business models, technology, methods through which m-payments could be carried out, and operational arrangements for delivering m-payments. By designing regulations before any m-payment service was launched and before considering any approvals-in-principle, the CBN did not have the opportunity to understand the service before it issued regulations. Secondly, the CBN failed to take advantage of the chance to gather relevant information during the mandated pilots. The $\mathrm{CBN}$ required applicants to build and pilot m-payment platforms within three months. This pilot period was short, and only two applicants met the deadline. ${ }^{124}$ This contrasts with Kenya, where m-pesa was piloted with the CBK's support two years before its launch. ${ }^{125}$ This gave sufficient time for Safaricom to adjust its product offering to reflect market needs and also gave the CBK more time to gather information on the product. ${ }^{126}$ The CBN's short mandatory pilot period arguably failed to give applicants enough time to adjust their product offering. It also does not appear that the pilots enabled the CBN to gather further information that would influence regulations. This is because the regulatory framework was not updated until four years after the pilots.

The contrast in the experiences of Kenya and Nigeria highlights the dilemma that authorities face in deciding what regulatory approach is more appropriate for innovative products. No consensus exists on the most suitable regulatory strategy. While some writers suggest full regulation resembling prudential banking regulations, others call for a "tailored regime" and warn against "unnecessary or over-reactive" regulation. ${ }^{127}$ Although Nigeria's early adoption of full regulations can be interpreted as heavy-handed, it can be justified on the basis that maintaining the safety of the financial system is at the core of the mandate of central banks. ${ }^{128}$ However, the problem rests in the inability to draw a balance between protecting the financial system and encouraging innovation, which in turn can increase inclusion. Since innovation can positively impact financial inclusion, it is reasonable to embrace a

124 Ibid.

125 M-pesa's pilot ran from October 2005 to October 2006: N Hughes and S Lonie "M-pesa: Mobile money for the 'unbanked' turning cellphones into 24-hour tellers in Kenya" (2007) 2/1 Innovations: Technology, Governance, Globalization 63 at 74 and 77.

126 International Finance Corporation "M-money channel distribution case: Kenya Safaricom m-pesa" at 4, available at: <http://documents.worldbank.org/curated/en/83 $2831500443778267 /$ pdf/117403-WP-KE-Tool-6-7-Case-Study-M-PESA-Kenya-Series-IFC-mob ile-money-toolkit-PUBLIC.pdf> (last accessed 2 July 2021).

127 M Crowe, M Kepler and C Merritt "The US regulatory landscape for mobile payments: Summary report of meeting between mobile payments industry workgroup and federal and state regulators on April 24, 2012" at 11, available at: <https://www.frbatlanta.org//media/documents/rprf/rprf_pubs/120730wp.pdf> (last accessed 3 July 2021); R Bollen "A discussion of best practice in the regulation of payment services: Part 1" (2010) 25/8 Journal of International Banking Law \& Regulation 370 at 373.

128 O Bar-Gill and E Warren "Making credit safer" (2009) 157 University of Pennsylvania Law Review 1 at 90. 
flexible regulatory approach like Kenya's, which can adapt to changes in the financial services landscape. ${ }^{129}$

Regulators can implement Kenya's test and learn approach in ways that best fit their jurisdictions. An increasingly popular and more structured option is the use of regulatory sandboxes. ${ }^{130}$ A regulatory sandbox is a "safe space in which businesses can test innovative products, services, business models and delivery mechanisms without immediately incurring all the normal regulatory consequences of engaging in the activity in question". ${ }^{131}$ With standardized eligibility requirements, sandboxes aim to encourage competitive innovation while enhancing the open and transparent exchange of information between regulators and innovators. ${ }^{132}$ Such a flow of information can inform future regulatory policies. In our context, sandboxes can be useful for emphasizing financial inclusion objectives. Where this is a policy priority, regulators can implement thematic sandboxes where preference is given to innovation that supports inclusion. ${ }^{133}$

As a recent approach to regulating financial services innovation, there is not yet enough empirical evidence of the impact of sandboxes. ${ }^{134}$ However, early research suggests that, while sandboxes can contribute to developing evidencebased policy, they are insufficient in themselves in promoting innovation or financial inclusion. ${ }^{135}$ Hence, regulators must engage in implementing broader reforms that support innovation, regulatory capacity, market engagement and financial inclusion. ${ }^{136}$ As sandboxes are not a "one-size-fits-all" solution, some researchers call for a focus on broader alternatives that reflect the priorities and capacity of regulators, as well as encouraging the general development of

129 E Eraker, C Hector and C Hoofnagle "Mobile payments: The challenge of protecting consumers and innovation" (2011) 10 Privacy \& Security Law Report 212 at 216.

130 L de Koker, N Morris and S Jaffer "Regulating financial services in an era of technological disruption" (2020) 36/2 Law in Context 90 at 95.

131 Financial Conduct Authority "Regulatory sandbox" (2015), para 1.2, available at: <https:// www.fca.org.uk/publication/research/regulatory-sandbox.pdf> (last accessed 3 July 2021).

132 M Wechsler, L Perlman and N Gurung "The state of regulatory sandboxes in developing countries" (2018) at 24, available at: <https://ssrn.com/abstract=3285938> (last accessed 3 July 2021).

133 Central banks in Sierra Leone and Malaysia have adopted this approach: S Duff "A growing trend in financial regulation: Thematic sandboxes" (CGAP blog 14 February 2019), available at: <https://www.cgap.org/blog/growing-trend-financial-regulation-thematic-s andboxes> (last accessed 3 July 2021).

134 FinTech Working Group of the UN Secretary-General's Special Advocate for Inclusive Finance for Development and Cambridge Centre for Alternative Finance "Early lessons on regulatory innovations to enable inclusive fintech: Innovation offices, regulatory sandboxes, and regtech" (2019) at 29, available at: <https://www.unsgsa.org/files/2915/5016/4448/Early_ Lessons_on_Regulatory_Innovations_to_Enable_Inclusive_FinTech.pdf> (last accessed 3 July 2021). Id at 30 .

136 Ibid. 
innovation ecosystems. ${ }^{137}$ These alternatives could focus on providing dedicated spaces (such as innovation hubs) or institutions (such as innovation offices) aimed at supporting innovators.

\section{Niche financial institutions may present an attractive compromise but do not guarantee results}

As indicated earlier, the latest regulatory update in Nigeria has seen the introduction of niche financial institutions (PSBs), which are permitted to provide m-payments. Under the new framework, MNOs through their subsidiaries can participate directly in providing m-payments. This appears to be a compromise between two policy positions: excluding MNOs from providing the service; and allowing them to participate directly, but within the regulatory control of the CBN. The idea of PSBs is not novel and Nigeria may have been inspired by India. Like Nigeria, India's initial response to regulating m-payments was to exclude MNOs from providing the service. Only licensed banks with a physical presence in India were initially permitted to offer m-payments. ${ }^{138}$ These services were also restricted to existing bank customers and / or credit and debit cardholders. ${ }^{139}$ Justifying its initial strict bank-led approach, the then deputy governor of the Reserve Bank of India (RBI) declared that the RBI believed that, "sustainable financial inclusion is achievable only through mainstream financial institutions, ie banks". ${ }^{140}$ He further explained that, "[i]n India, we have adopted a bank-led model for financial inclusion, which seeks to leverage on technology ... Our experience shows that the goal of financial inclusion is better served through mainstream banking institutions as only they have the ability to offer the suite of products required to bring in effective / meaningful financial inclusion". ${ }^{141}$

In 2014, the RBI adjusted its stance by opening the playing-field to nonbanks. ${ }^{142}$ However, it held onto its initial belief that banking institutions were better placed to drive inclusion. Hence, the RBI only permitted nonbanks to provide payment services if they registered as newly created banking

137 RP Buckley et al "Building fintech ecosystems: Regulatory sandboxes, innovation hubs and beyond" (2020) 61 Washington University Journal of Law \& Policy 55 at 58; UNSGSA FinTech Working Group and CCAF "Early lessons", above at note 134 at 20; I Jenik and K Lauer "Regulatory sandboxes and financial inclusion" (CGAP working paper, October 2017) at 10, available at: <https:/www.cgap.org/sites/default/files/Working-PaperRegulatory-Sandboxes-Oct-2017.pdf> (last accessed 3 July 2021).

138 RBI "Mobile banking transactions in India: Operative guidelines for banks", para 6.1, available at: <https://www.rbi.org.in/scripts/FS_Notification.aspx?Id=10509\&fn=9\&Mo de $=0 \# 6>$ (last accessed 3 July 2021).

139 Id, para 6.2 .

140 KC Chakrabarty "The first mile walk into financial inclusion: Thinking differently" (address by the deputy governor, RBI, Financial Inclusion Conference, 2012), para 14, available at: <http://www.agloc.org/pdf/august_07_2012.pdf> (last accessed 3 July 2021).

141 Id, para 12.

142 RBI "Guidelines for licensing of payments banks", available at: <https://rbi.org.in/scripts /bs_viewcontent.aspx?Id=2900> (last accessed 3 July 2021). 
institutions (payments banks) offering a range of financial services. Accordingly, it issued Guidelines for the Licensing of Payments Banks (Licensing Guidelines). ${ }^{143}$ The RBI stated that the primary objective for introducing payments banks was to further financial inclusion. ${ }^{144}$ MNOs, supermarket chains, non-banking finance companies and public sector companies are among the classes of persons eligible to apply for licences. ${ }^{145}$ The regulatory change provided leeway for MNOs to participate in the provision of m-payments. As in Nigeria, payments banks may provide savings accounts and payment / remittance services, but cannot offer credit. ${ }^{146}$

The justification for payments banks is that they offer a broad suite of services beyond m-payments. Their provision of additional services reflects the RBI's belief that a superior model for improving inclusion is one that supports additional banking services alongside m-payments. ${ }^{147}$ While this is an important consideration, if there is no demand for the additional services, then the introduction of payments banks may be strategically unwise. This is because, for innovation to succeed, it should be designed to respond to an unmet need expressed by consumers and should not be based on assumptions of what consumers want. ${ }^{148}$ Some examples buttress this point. M-pesa is partly successful because the product's design addressed the existing need for low cost person-to-person transfers. ${ }^{149}$ Although the initial product proposal focused on microfinance transactions, consumer feedback during the pilot prompted changes that made the product functionally relevant. ${ }^{150}$ Reflecting the market need at its launch, Safaricom focused on providing a convenient and costeffective domestic platform for sending money from urban areas to rural communities. ${ }^{151}$ This can be contrasted with unsuccessful attempts in other jurisdictions. In South Africa, for instance, a product called WIZZIT was introduced to provide a full suite of banking services to the unbanked. Besides stiff

143 This approach is described as the "narrow banking" model, where banking licences are granted to non-banking firms to carry out deposit and payment services but not credit services. See Mobile Money Association of India and the GSM Association "Mobile money: The opportunity for India" (position paper, 13 November 2013) at 19, available at: <https:// www.gsma.com/mobilefordevelopment/wp-content/uploads/2013/12/MMAI-GSMA-onMobile-Money-in-India-for-RBI-Financial-Inclusion-Committee_Dec13.pdf> (last accessed 13 April 2020).

144 RBI "Guidelines for licensing", above at note 142, para 2.

145 Ibid.

146 Id, para 4.

147 KC Chakrabarty "M-banking in India: Regulations and rationale" (address by deputy governor, RBI, International Banking Summit on Regulation of Cross-Border Mobile Payments and Regional Financial Integration, Mumbai, 29 March 2012), available at: <http://www.bis.org/review/r120330f.pdf> (last accessed 3 July 2021).

148 Riley and Kulathunga Bringing E-Money to the Poor, above at note 77 at 57.

149 Lashitew et al "Mobile phones for financial inclusion”, above at note 91 at 1209.

150 Ibid.

151 ES Kobor "The role of anti-money laundering law in mobile money systems in developing countries" (2013) 8 Washington Journal of Law, Technology E Arts 303 at 307-08. 
regulatory roadblocks faced by WIZZIT's founders, a Harvard study suggests that one of the reasons behind the product's failure was that it was launched without much consideration of the market demand for the services offered. ${ }^{152}$

So far, payments banks have not made a substantial impact in India. While 11 in-principle approvals were granted to applicants in 2015, by 2018 only four of those 11 remained operational. ${ }^{153}$ These banks registered weak performances, incurring net losses in the financial years 2016-17 and 2017-18. ${ }^{154}$ Their lacklustre performance has been attributed to limited revenue streams. ${ }^{155}$ This is a direct consequence of stringent regulations that dictate the business model that they can adopt. ${ }^{156}$ Although registered as banks, they are prohibited from engaging in any lending activity and cannot make any profit from interest. The revenue margins from deposits are also small as there is a cap on the deposits that they can accept. ${ }^{157}$ At the same time, they must offer attractive interest rates on deposits if they wish to compete with traditional banks. ${ }^{158}$

Although it is too early to assess fully the impact of niche institutions like payments banks, two points must be made. First, while it is important that excluded persons can access a wide range of financial products in the longterm, it may be more sustainable to allow providers to develop products organically that reflect market needs. Hence, user-driven extensions of essential payment services may be more viable in the long term. Understanding the needs of the underserved and building their trust and familiarity with basic digital financial services is likely to convert them into account-holders in the long-term. ${ }^{159}$ M-pesa continues to stay relevant because it constantly adapted and extended its functionalities based on customer feedback and changing market trends. ${ }^{160}$ From focusing on basic services like facilitating person-to-person payments, airtime purchases and cash withdrawals from agents, m-pesa has expanded its services over the years to include transfers

152 VK Rangan and K Lee "Mobile banking for the unbanked" (2012), available at: <https:// www.hbs.edu/faculty/Pages/item.aspx?num=39405> (last accessed 3 July 2021).

153 SK Reddy and SA Sarat "Announcement of payment banks and stock performance of commercial banks in India” (2018) 23/1 Journal of Internet Banking and Commerce 1 at 4.

154 Report on Trend and Progress of Banking in India 2017-18 (2018, RBI), available at: <https:// rbidocs.rbi.org.in/rdocs/Publications/PDFs/0RTP2018_FE9E97E7AF7024A4B94321734CD 76DD4F.PDF> (last accessed 3 July 2021).

155 R Merwin "Why five out of the 11 payments banks have shut shop" (10 September 2019) The Hindu BusinessLine, available at: <https://www.thehindubusinessline.com/money-andbanking/five-out-of-the-11-payments-banks-have-shut-operations-why/article29381134.ece> (last accessed 3 July 2021).

156 State Bank of India "Payments banks: A case of near yet too far" (22 July 2019), available at: <https://sbi.co.in/documents/13958/126691/Ecowrap_20190722.pdf> (last accessed 3 July 2021).

157 They cannot accept deposits over 1 lakh: ibid.

158 Merwin "Why five out of the 11", above at note 155.

159 Riley and Kulathunga Bringing E-Money to the Poor, above at note 77 at 57.

160 Lashitew et al "Mobile phones for financial inclusion", above at note 91 at 1209. 
to and from regular bank accounts, international remittances and microinsurance. ${ }^{161}$ It also went on to partner with the Commercial Bank of Africa to offer M-Shwari, a micro-credit service. ${ }^{162}$

Secondly, India's experience raises questions about whether niche banking institutions will encourage MNO involvement in driving the m-payments market. India's experience may suggest that such institutions can disincentivize MNOs from investing. MNOs are not financial institutions but will be subject to stringent banking regulations if they register as niche banking institutions. With restrictions on their activities limiting the profits that they can make, they may decide that investing in the market is not entirely justified.

\section{Regulators must carefully consider which mobile payment models will best achieve identified policy goals}

M-payments can be provided using several business models. There are divergent views on which model is best suited for driving the market. For instance, Rajan argues that the best model for m-payments is one where MNOs only act as intermediaries between consumers and financial institutions. ${ }^{163}$ This view is justified on the basis that financial regulations are onerous and limiting the role of MNOs to intermediaries will ensure that the cost of extending financial regulations to MNOs is avoided. ${ }^{164}$ Moreover, while innovations like m-payments can increase financial inclusion, they are disruptive and can introduce negative externalities. ${ }^{165}$ These externalities may include prudential risks, which can negatively affect the safety of the financial system. Non-banking institutions have not traditionally been saddled with managing financial transactions and, therefore, have a limited understanding of the prudential risks involved. Their limited experience further suggests that they will also have limited risk management capabilities. ${ }^{166}$ Arguments in favour of bank-led models are often justified on the basis of these points.

In contrast, commentators such as Alexandre et al argue that, in jurisdictions where banks cannot profitably serve a significant number of people, regulators should allow a broader range of participants, which face different cost structures and economic incentives, to contest the market directly. ${ }^{167}$ Supporting this view, Porteous argues that, given the weakness of the retail banking sector in many developing countries, it is necessary that non-bank

161 Id at 1208; Hughes and Lonie "M-pesa: mobile money", above at note 125 at 78.

162 P Ondiege "Regulatory impact on mobile money and financial inclusion in African countries: Kenya, Nigeria, Tanzania and Uganda” (Center for Global Development, March 2015) at 22, available at: <https://www.cgdev.org/sites/default/files/Background-PaperFinancial-Inclusion-Ondiege.pdf> (last accessed 3 July 2021).

163 MA Rajan "The future of wallets: A look at the privacy implications of mobile payments" (2012) 20 Commercial Law Conspectus 445 at 468-69.

164 Ibid.

165 Riley and Kulathunga Bringing E-Money to the Poor, above at note 77 at 64.

166 Id at 47.

167 Alexandre et al "Regulating new banking models", above at note 79. 
players, particularly MNOs with their strong retail brands and established networks, be able to issue e-money. ${ }^{168}$ He further argues that, even if non-banks decide not to invest, the threat of possible entry may galvanize a response from banks. ${ }^{169}$ Under this approach, non-bank players like MNOs may be permitted to provide m-payments directly in different ways. One method may allow MNOs to acquire direct licences to provide the service without any substantial changes to their structure. This was the case with Kenya's m-pesa. Another method may require that they participate through niche banking institutions, as is the case in India and Nigeria.

While banks and MNOs remain critical to providing fund settlement and mobile network facilities respectively, m-payments can be provided by other electronic money firms that are neither banks nor MNOs. ${ }^{170}$ The involvement of such firms promises a more competitive market that will leave consumers with increased choices. While promising, this model can face certain difficulties. First, initial investment costs will be high, as such providers will need to enter separate agreements with participating banks and MNOs to run their service. Secondly, where such providers are new, they may not be popular enough to inspire consumer trust, and many excluded persons may refrain from embracing their services. Thirdly, such providers may have limited agent networks due to the high costs of establishing them. If this is the case, they will struggle to achieve the coverage that MNOs and, to a lesser extent, banks enjoy. This will mean that, in many developing countries, they may not gain traction outside urban areas. Finally, owing to the scale of the services that they provide, MNOs and banks are well-experienced in operations management, which other providers may not be. Where providers lack such capacity, their inexperience can lead to operational challenges, which may erode their business. ${ }^{171}$

Some writers argue for hybrid models involving alliances between the two crucial parties in the m-payments transaction process: banks and MNOs. This model is thought to represent the most beneficial model for all parties

168 D Porteous "The enabling environment for mobile banking in Africa" (report commissioned by Department for International Development, May 2006) at 50, available at: <https://www.findevgateway.org/sites/default/files/publications/files/mfg-en-paper-theenabling-environment-for-mobile-banking-in-africa-may-2006_0.pdf> (last accessed 15 July 2021).

169 Ibid.

170 PL Chatain et al Protecting Mobile Money Against Financial Crimes: Global Policy Challenges and Solutions (World Bank, 2011) at 10, 19 and 66, available at: <http://documents1.wo rldbank.org/curated/en/854951468337169489/pdf/600600PUB0ID181Mobile0978082138 6699.pdf> (last accessed 3 July 2021).

171 For example, in 2013 the Bank of Zambia revoked the mobile money licence granted to Celpay, a payment services provider, due to operational challenges it faced coupled with allegations of mismanagement and fraud: B Cooper et al "Zambia payments diagnostic" (November 2019) at 20, available at: <https://cenfri.org/wp-content/uploads/Zambiapayments-diagnostic_Cenfri_BankServAfrica.pdf> (last accessed 3 July 2021). 
involved, because it allows them to retain their core functions. ${ }^{172}$ Where collaboration occurs, banks will leverage their experience in settling payments, while MNOs will leverage the extensive reach of their agent networks. While this model has its advantages, collaboration between key stakeholders can be challenging to achieve. For example, despite m-pesa's success, Safaricom's ${ }^{173}$ early attempts to collaborate with a bank (Equity Bank) in introducing another platform, M-kesho, were unsuccessful. This failure was partly attributed to the difficulty associated with managing complex issues, like the division of responsibilities and the sharing of revenue, which led to friction. ${ }^{174}$ Despite these challenges, this model may be the most sustainable in the long term since it combines the advantages of the bank-led and MNO-led models. A model that allows parties to focus on their core competencies will probably make the most economic sense to competing participants. Hence, in the long run, it is anticipated that participants may voluntarily choose to collaborate in offering m-payments. As Alexander et al point out:

"Product development will remain the preserve of banks, as telecom companies have no expertise and likely no desire to develop financial products beyond basic transactional services. This difference in aspirations and comparative advantages should establish a strong basis for partnerships between mobile operators that will be motivated by the growth in transaction volume and banks that will be more interested in accessing float and cross-selling and up-selling products to clients". ${ }^{175}$

While agreeing that a hybrid may be the most useful model, it is submitted that such collaborative partnerships should occur organically, based on voluntary terms agreed between participants. If regulators mandate hybrids, participants may be reluctant to invest if they are not ready to make the necessary commitments. Affirming this argument, in many countries where providing m-payments is not restricted to banks, MNOs have chosen to partner with them. ${ }^{176}$ Although the Kenyan Bankers Association initially resisted m-pesa, many Kenyan banks incorporated m-pesa with their own core applications

172 L Chaix and D Torre "Four models for mobile payments" (2011), available at: <https:// www.researchgate.net/profile/Dominique_Torre/publication/267917243_Four_models_for_ mobile_payments/links/547486d00cf2778985abe525/Four-models-for-mobile-payments. pdf?origin=publication_detail> (last accessed 3 July 2021).

173 The MNO behind m-pesa.

174 G Demombynes and A Thegya "Kenya's mobile revolution and the promise of mobile savings" (World Bank, Africa Region, Poverty Reduction and Economic Management Unit policy research working paper 5988, March 2012) at 15, available at: <http://do cuments.worldbank.org/curated/en/900911468047101453/pdf/WPS5988.pdf> (last accessed 3 July 2021).

175 Alexandre et al "Regulating new banking models", above at note 79 at 121.

176 In respect of Côte d'Ivoire, Kenya, Rwanda, Tanzania and Uganda, see: Evans and Pircho "An empirical examination", above at note 69 at 14. 
to reduce their operational costs, setting the stage for further collaboration. Since 2010, Safaricom, the MNO behind m-pesa, has formed partnerships with several banks to offer other products, like savings accounts, micro-credit and insurance. ${ }^{177}$

In deciding what model to promote, regulators must consider how the merits and demerits of the different arrangements highlighted above can impact identified policy objectives. Porteous argues that enabling regulatory environments should allow for the development of business models that meet a defined policy objective. ${ }^{178}$ Hence, if a regulator's objective is to increase financial inclusion using m-payments, then it ought to support the models that can make this possible. If a significant percentage of a country's populace cannot access formal financial services due to limited bank branches or service channels, then regulators should embrace models that encourage the participation of actors that have good agent networks in underserved areas. This suggests that MNO-led models or hybrid models will probably record transformative success in comparison to bank-led models. This is because, if a primary reason for exclusion is poor bank branch penetration, addressing this problem by introducing a bank-centric solution only leads back to the origin of the problem. If regulation places banks at the centre of driving the m-payments market, it indirectly makes a relationship with a bank a prerequisite for m-payments, which in effect shuts out already excluded consumers.

In many countries where mobile money services have contributed to increasing inclusion, regulations have permitted flexible models that support the participation of the stakeholders with extensive agent networks. Apart from Kenya, another example may be seen in Bangladesh. Bangladesh has taken advantage of the extensive reach of its post office network to encourage models that allow for the delivery of digital financial services. The post office department has an extensive network of 9,886 post offices across the country, which has proved vital in providing a mobile money order service. ${ }^{179}$ This department provides a mobile money order service in partnership with the second largest MNO in Bangladesh (Banglalink Mobile Company), which has an extensive network coverage area. This partnership enables the service to be accessible at numerous postal outlets, including in areas with little or no internet connectivity. ${ }^{180}$

177 In 2010, it launched a product called M-kesho with Equity Bank; in 2012, it launched M-Shwari with the Commercial Bank of Africa and KCB m-pesa with the Kenyan Commercial Bank: Lashitew et al "Mobile phones for financial inclusion", above at note 91 at 1211.

178 D Porteous "Mobilizing money through enabling regulation" (2009) 4/1 Innovations, Technology, Governance, Globalization 75 at 77.

179 N Kachingwe and A Berthaud "Bangladesh: An unexpected source of branchless banking innovation?" (December 2013) at 7, available at: <https://www.findevgateway.org/casestudy/2013/12/bangladesh-unexpected-source-branchless-banking-innovation> (last accessed 15 July 2021).

180 Id at 9 . 


\section{LOOKING AHEAD: THINKING BEYOND THE PLAYERS AND FOCUSING ON THE REGULATORY RISKS}

M-payments raise several regulatory concerns, which may include the potential abuse of the financial system, data protection risks and consumer protection challenges. For regulators wishing to leverage m-payments in driving financial inclusion, the key consideration should be how they can design appropriate responses that address these risks. This is because the positive impact of any form of innovation, including m-payments, will only remain credible in the long term if regulators can identify and address the specific risks that attract negative externalities. Accordingly, regulatory resources are best channelled towards analysing trends in the m-payments market to identify and understand risks, and design safeguards to address them. ${ }^{181}$

For instance, where regulators permit non-banking institutions to provide m-payments, those institutions are unlikely to have the sophisticated experience required for asset and liquidity management. This inexperience can introduce systemic risks, requiring regulators to adopt mechanisms that can lessen the risks. In Kenya for example, the NPSR introduce a core capital requirement for authorized PSPs. ${ }^{182}$ PSPs are also prohibited from engaging in any lending or investment activity unless expressly permitted under the NPSR. ${ }^{183}$ Where a PSP is involved in other unrelated ventures, it must keep its payment service in a separate business unit, and must maintain a separate management structure and books of account. ${ }^{184}$ PSPs are consequently mandated to create a trust to cover consumer funds. ${ }^{185}$ They are also obliged to adopt appropriate risk mitigation strategies that ensure that consumer funds are placed in commercial banks and diversified. ${ }^{186}$

Similarly, in India, payments banks are required to invest 75 per cent of their demand deposit balances in government securities / treasury bills with a maturity of up to one year. ${ }^{187}$ They must also hold a maximum of 25 per cent in current and time / fixed deposits with other scheduled commercial banks. ${ }^{188}$ All other financial and non-financial activities of a bank's promoters must be ring-fenced and should not be mingled with the banking and financial services business of the payments bank. ${ }^{189}$ To provide a buffer

181 Riley and Kulathunga Bringing E-Money to the Poor, above at note 77 at 55; S di Castri "Mobile money: Enabling regulatory solutions" (February 2013), available at: <https:// www.gsma.com/mobilefordevelopment/wp-content/uploads/2013/02/MMU-EnablingRegulatory-Solutions-di-Castri-2013.pdf> (last accessed 3 July 2021).

182 NPSR, reg 11.

$183 \mathrm{Id}$, reg 45.

$184 \mathrm{Id}$, reg 28(2)(d).

$185 \mathrm{Id}$, reg 25(3).

186 Id, reg 28(2)(d).

187 Such securities must be recognized by the RBI as eligible securities for the maintenance of their statutory liquidity ratio: RBI "Guidelines for licensing”, above at note 142, para 5.

188 These are for operational purposes and liquidity management: ibid.

189 Ibid. 
against operational risks, the RBI requires that a minimum paid-up equity capital of one hundred crores (approximately GBP 9.6 million) be maintained. ${ }^{190}$

Another critical concern for regulators is ensuring that innovation does not leave the financial system open to abuse. To achieve this, regulators must impose arrangements that seek to maintain financial integrity. For instance, the potential misuse of the financial system may be mitigated by requiring providers to adopt customer registration and verification measures that ensure that persons using the services can be identified. In reality, it can be difficult to balance such arrangements with financial inclusion policies. This is because regulators and regulated institutions are often cautious about breaching international standards aimed at combating abuse of the financial system. This can lead to inflexible and inappropriate measures that may prevent people from accessing formal financial services. ${ }^{191}$ For instance, in many developing countries, some persons find themselves financially excluded because they cannot satisfy regulatory requirements, such as those mandated for customer identification and verification purposes. ${ }^{192}$ To address this, the Financial Action Taskforce (FATF), the lead inter-governmental body that sets standards aimed at combating money laundering and terrorist financing, has released several guidance documents to support regulators. ${ }^{193}$ Central to the FATF's advice is a call for money laundering and terrorist financing regulators to apply a risk-based approach. ${ }^{194}$ This means that regulators should develop flexible and proportionate responses that address actual risks flagged up in their risk assessment. The understanding is that, if regulators take advantage of the flexibility allowed by the risk-based approach, they

190 Ibid.

191 J Isern and L de Koker "AML / CFT: Strengthening financial inclusion and integrity" (CGAP focus note no 56, August 2006) at 4, available at: <https://www.cgap.org/sites/default/files /researches/documents/CGAP-Focus-Note-AML-CFT-Strengthening-Financial-Inclusion-andIntegrity-Aug-2009.pdf> (last accessed 3 July 2021).

192 de Koker "Aligning anti-money", above at note 9; L de Koker "Money laundering control and suppression of financing of terrorism: Some thoughts on the impact of customer due diligence on financial exclusion” (2006) 13/1 Journal of Financial Crime 26.

193 FATF "Guidance for a risk-based approach: Prepaid cards, mobile payments and internetbased payment services" (June 2013), available at: <https://www.fatf-gafi. org/media/fatf/documents/recommendations/Guidance-RBA-NPPS.pdf> (last accessed 3 July 2021); FATF "Anti-money laundering and terrorist financing measures and financial inclusion” (June 2011), available at: <https://www.fatf-gafi.org/media/fatf/content/images /AML\%20CFT\%20measures\%20and\%20financial\%20inclusion.pdf> (last accessed 3 July 2021); FATF "Guidance on the risk-based approach to combating money laundering and terrorist financing: High level principles and procedures” (June 2007), available at: <https ://www.fatf-gafi.org/media/fatf/documents/reports/High\%20Level\%20Principles\%20and\% 20Procedures.pdf> (last accessed 3 July 2021).

194 FATF "International standards on combating money laundering and the financing of terrorism \& proliferation: The FATF recommendations" (updated October 2020), recommendation 1, available at: <http://www.fatf-gafi.org/media/fatf/documents/reco mmendations/pdfs/FATF\%20Recommendations\%202012.pdf> (last accessed 3 July 2021). 
can tailor measures that are attuned to their jurisdictions and will not negatively impact financial inclusion.

The FATF also requires that financial institutions develop internal policies that address money laundering and terrorist financing risks ${ }^{195}$ and encourage the inclusion of AML / CFT ${ }^{196}$ risk assessments in the development of new products. ${ }^{197}$ The m-pesa development process exemplifies adherence to this. ${ }^{198}$ As discussed earlier, the CBK satisfied itself that the product was designed to mitigate money laundering and terrorist financing risks and that Safaricom's internal AML / CFT policy was sufficient. This was reflected in functionalities that supported transaction caps, ${ }^{199}$ suspicious transaction reporting ${ }^{200}$ and the generation of electronic transactional trails. ${ }^{201}$

Practical implementation of the FATF guidance will require that regulators also implement other broader reforms. For example, to ensure that customer identification and verification processes are not exclusionary, regulators must develop national identification systems, which will make it easier for excluded persons to satisfy such requirements. Beyond Kenya's regulatory flexibility, m-pesa's success has also been attributed to the fact that Kenya already had a workable national identification system when it was launched. This helped to lessen the customer registration and verification requirements needed to open an m-pesa account. ${ }^{202}$

De Koker and Jentzsch point out that, while adherence to the FATF standards promises increased transparency in the financial system, it can introduce other considerations from a privacy perspective. ${ }^{203}$ AML procedures require that personal information about customers as well as their transaction trails are collected and stored. In developing countries with weak data protection frameworks, this can be problematic. The potential for unremedied data breaches and the likelihood that personal and transaction information can be

$195 \mathrm{Id}$, recommendation 18.

196 CFT is an acronym for "combatting the financing of terrorism".

197 FATF "International standards", above at note 194, recommendation 15.

198 Chatain et al Protecting Mobile Money, above at note 170 at 126.

199 Reflecting FATF guidance at the time that value limits were lower risk. See FATF "Report on new payment methods" (13 October 2006) at 10, available at: <https://www.fatf-gafi. org/media/fatf/documents/reports/Report $\% 20$ on $\% 20$ New\%20Payment $\% 20$ Methods.pdf> (last accessed 3 July 2021). This guidance remains in FATF's updated report: FATF Money Laundering Using New Payment Methods (October 2010), available at: <https://www.fatf-gafi. org/media/fatf/documents/reports/ML\%20using\%20New\%20Payment\%20Methods.pdf> (last accessed 3 July 2021).

200 In line with FATF "International standards", above at note 194, recommendation 20.

201 In line with id, recommendation 11.

202 C Alexandre and M Almazan "From cash to electronic money: Enabling new business models to promote financial inclusion and financial integrity" in J Osikena (ed) The Financial Revolution in Africa: Mobile Payment Services in a New Global Age (2012, Foreign Policy Centre) 11 at 12.

203 L de Koker and N Jentzsch "Financial inclusion and financial integrity: Aligned incentives?” (2013) 44 World Development 267 at 270. 
misused, even by government authorities, may discourage people from transacting within the formal financial sector. ${ }^{204}$ To alleviate these concerns, regulators and lawmakers must design robust privacy and data protection laws.

Excluded persons are usually the target of innovative products that seek to drive inclusion. Because these persons are often vulnerable due to their circumstances, regulators must design measures that ensure that they are no worse off in adopting such services. ${ }^{205}$ Such efforts will cover issues such as protecting consumer funds, which can be addressed by the prudential measures discussed above. These efforts should also address other consumer protection concerns that may lead to personal consumer detriment. ${ }^{206}$ With m-payments, for instance, consumers may be subjected to unfair commercial practices, such as the use of unfair contract terms. M-payment services will be offered to consumers on standard form contracts, which will be available on a take it or leave it basis. Such contracts are prone to abuse, as they are one-sided and cannot be negotiated. This problem is exacerbated in many developing countries where illiteracy levels are high, making it almost impossible for consumers to understand the consequences of the terms on which they contract.

Tackling the use of unfair commercial practices will require wider legislative reforms that are broadly drafted to accommodate technological innovation. As stated earlier, m-pesa's success highlighted regulatory gaps that spurred legislative reforms in several areas, including consumer protection frameworks. One of the aims of the Kenyan Consumer Protection Act, which was passed in 2021, was to protect "consumers from all forms and means of unconscionable, unfair, unreasonable, unjust or otherwise improper trade practices including deceptive, misleading, unfair or fraudulent conduct”. ${ }^{207}$ Such regulatory intervention is necessary to protect consumers, especially those who may be more susceptible to certain unfair practices owing to reasons such as age, illiteracy, mental disability and poverty.

To ensure that regulators can understand and respond adequately to the different risks associated with innovation, they will need to step up their supervision and oversight capabilities. ${ }^{208}$ This will require them to work with participants in the ecosystem to understand the products being offered as

204 Ibid.

205 K McKee, M Kaffenberger and JM Zimmerman "Doing digital finance right: The case for stronger mitigation on customer risks" (CGAP focus note no 103, June 2015), available at: <https://www.cgap.org/sites/default/files/Focus-Note-Doing-Digital-Finance-Right-Jun2015.pdf> (last accessed 3 July 2021).

206 This represents the "negative outcomes for individual consumers that they become aware of following the purchase or use of a good or service, measured relative to what would reasonably have been expected given the type of transaction": European Commission "Study on measuring consumer detriment in the European Union" (February 2017) at 28, available at: <https://ec.europa.eu/info/sites/info/files/cons umer-detriment-study-final-report_en.pdf> (last accessed 3 July 2021).

207 Consumer Protection Act, sec 3(4)(d)

208 Riley and Kulathunga Bringing E-Money to the Poor, above at note 77 at 55. 
well as the attendant risks. This approach would ensure that regulators retain access to critical information in a fast-changing innovative marketplace, allowing them to adjust their regulatory policies where required. ${ }^{209}$ In many cases, regulators will also need to work closely with legislative authorities to design appropriate legislative responses where necessary.

\section{CONCLUSION}

In developing countries with high mobile penetration rates, m-payments can assist in extending financial services to the unbanked populace. Consequently, the service has drawn the attention of regulators. While regulatory responses to innovation must be country-specific and tailored to suit local realities, policymakers seeking to leverage innovation for financial inclusion should learn from the experiences of other countries. Reflecting on Nigeria's experience, this article concludes that, while high mobile penetration rates are a strong indicator that m-payments may flourish in a given jurisdiction, their success largely depends on the regulatory environment.

More specifically, the article first argued that one reason for the dismal success of m-payments in Nigeria was the CBN's initial decision to exclude MNOs from providing m-payments services directly. Given their extensive agent networks, the article argued that the direct participation of MNOs in m-payments is crucial in driving efforts to improve inclusion. Recent regulatory changes support this view. Secondly, contrasting the CBN and CBK approaches to the early regulation of m-payments in their respective jurisdictions, the article highlighted the importance of flexible regulatory approaches that encourage communication between regulators and innovators. Such approaches may achieve a better balance between protecting the financial system and leveraging innovation to drive inclusion. Thirdly, while acknowledging policy shifts in Nigeria that allow MNOs to participate in the market through niche banking institutions, the article highlighted the difficulties associated with this approach by drawing on India's experience.

Fourthly, the article suggested that, if financial inclusion is a policy priority, regulators should embrace models that encourage investment by providers with good agent networks in underserved areas. Accordingly, it argued that MNO-led models or hybrid models are more likely to record transformative success. Finally, the article proposed that a pragmatic approach to regulating innovation is one that seeks to understand and identify associated risks to enable regulators to design proportionate responses.

\section{CONFLICTS OF INTEREST}

None

209 Zetzsche et al "Regulating a revolution", above at note 108 at 61-62. 